(2) Open Access Full Text Article

EDITORIAL

\title{
Are reviewers obstructing stem cell research?
}

This article was published in the following Dove Press journal:

Stem Cells and Cloning:Advances and Applications

28 August 2010

Number of times this article has been viewed

\section{Bernard Binetruy \\ INSERM U626, Faculté de Médecine La Timone, Marseille, France}

Correspondence: Bernard Binetruy INSERM U626, Faculté de Médecine La Timone, 27, Bd Jean Moulin, 13385 Marseille Cedex 5, France

$\mathrm{Tel}+33491324406$

Fax + 33491254336

Email bernard.binetruy@univmed.fr
A current controversy in stem cell research was published on the $\mathrm{BBC}$ website recently. ${ }^{1}$ Some stem cell researchers have said that "they believe a small group of scientists is effectively vetoing high quality science from publication in journals". ${ }^{1}$ They strongly suspected some reviewers to be deliberately sending back negative comments or asking for unnecessary experiments. Nature editor, Dr Philip Campbell, has said that "this idea is utterly false". ${ }^{1}$

Although this accusation is very difficult to prove, such assumptions should be examined with great attention. One reason for this attention is because these accusations are coming from established experts in the field, and their opinions carry more weight than those coming from unknown researchers. The second reason for attention is that these accusations concern the field of stem cell work, and more specifically the field of induced pluripotent stem cells, which has accelerated from zero to "headlong rush" in under three years. ${ }^{2}$

Research on induced pluripotent stem cells is promising for regenerative medicine and its consequence is the injection of a lot of money into laboratories - which is a good thing - but this cash flow generates increasing appetites in turn, and these excesses constitute a potential problem.

To counter this research bias, a proposition has been made that a paper should be published together with its reviews and author responses available on the Internet as supplementary material. I think that this proposition has the great merit to be simple and probably very efficient. Indeed, one can imagine that a reviewer will take more care with his/her comments in the knowledge that they will be published alongside the paper.

Nature's editor said "he envisaged practical obstacles"" around this proposition, but didn't mention what they were. Monica Bradford, executive editor of Science, seems more open to the proposition, but her journal's policy is to continue "to preserve the confidentiality of reviewer's comments". ${ }^{1}$

While the convention in medical publishing tends towards anonymous and confidential comments, I don't really understand why the editors of these journals are so negative towards this proposition, which is full of good sense.

\section{References}

1. BBC. Journal stem cell work 'blocked'. 2010. Available from: http://news.bbc.co.uk/1/hi/sci/tech/8490291 stm. Accessed on Mar 10, 2010.

2. Baker M. Stem cells: Fast and furious. Nature. 2009;458:962-965. 


\section{Publish your work in this journal}

Stem Cells and Cloning: Advances and Applications is an international, peer-reviewed, open access journal. Areas of interest in stem cell research include: Embryonic cell stems; Adult stem cells; Blastocysts; Cordblood stem cells; Stem cell transformation and culture; Therapeutic cloning; Umbilical cord blood and bone marrow cells; Laboratory,

animal and human therapeutic studies; Philosophical and ethical issues related to stem cell research. This journal is indexed on CAS. The manuscript management system is completely online and includes a quick and fair peer-review system. Visit http://www.dovepress.com/ testimonials.php to read real quotes from published authors.

Submit your manuscript here: http://www.dovepress.com/stem-cells-and-cloning-advances-and-applications-journal 